第82回日本内科学会講演会（1985年）

\title{
最近の話題 睡眠無呼吸症候群*
}

藤田学園保健衛生大学医学部内科

梅田 博道

\section{RECENT MEDICAL TOPICS : SLEEP APNEA SYNDROMES}

Hiromichi UMEDA, MD

Prof., Department of Internal Medicine, School of Medicine,

Fujita-gakuen Health University, Toyoake

1956年Burwellら ${ }^{11} は ，$ 過度の肥満，過剰傾眠， 肺胞低換気，右心不全などを示す症候群を報告し， Pickwickian syndromeと名付けた。肥満と肺胞 低換気について多くの関心を集めるきつかけとな つたが，本症の病態の悪化に重要な因子となって いる睡眠無呼吸を始めて指摘したのは，それから 9 年後に報告したGastautら゙である。その後，睡 眠中の呼吸障害に関する研究が様々な面から進め られ，特にStanford大学のGuilleminault $ら^{3)} の$ 研 究を中心に極めて長足の進歩を遂げつつ今日に至 つている.

睡眠呼吸障害は，睡眠無呼吸，低換気， $\mathrm{O}_{2}$ 飽和 度の低下などの形で認められるが, Pickwikian症 候群のみでなく，極めて多くの疾患に関連して認 められ，時には突然死を招く原因となることさ兄 ある，その臨床的な重要性の認識は益々深まる一 方であり，呼吸不全および肺性心が関連する病態 の診断, 治療, 病因の解明に当つて, 睡眠呼吸障 害を除いては今日論じることが出来ない時代にな つたといえる。

\section{1. 睡眠無呼吸の定戥と分類}

睡眠中に10秒間以上同時に口と鼻の気流停止が 認められた場合に睡眠無呼吸とする．正常人でも 無呼吸は認められるが, 入眠初期の浅睡眠とREM 期に限られ，また反復性に現われることはない． また,一晚の睡眠中に30回以上起きることはない。 睡眠無呼吸症候群は，正常範囲以上の無乎吸が睡

*本講演は1985年 4 月 5 日，名古屋市千種区吹上 $2-6-3$ 名古屋市中小企業振興会館にて行なかれた。
眠中に認められ，その結果様々な臨床症状，徵候 を呈するに至つた状態であるといるる。

睡眠無呼吸には，呼吸中枢の障害によつて起き る中权型, 上気道閉塞によつて起きる閉塞型, 両 者が混ざつて起きる混合型の別がある，中权型に おいては，REM期に，呼吸中枢から呼吸筋へ送ら れる刺激が消失した状態となり，呼吸運動が停止 する． 1 回の無呼吸が 3 分間にも及ぶことがある が，その間に著しい低 $\mathrm{O}_{2}$ 括よび高 $\mathrm{CO}_{2}$ 血症に陥り 呼吸が再開する。いわゆるCheyne-Stokes様の周 期性呼吸を呈するのである，しかし，無呼吸に陌 つてる，閉塞型に見られるような睡眠の覚醒反応 は原則的に起きない，そして，本症の病態の悪化 は無呼吸によつて生じる $\mathrm{O}_{2}$ 不足が中心となり，重 症例では肺高血圧，肺性心へと発展する。閉塞型 においては，すべての睡眠期を通じて，上気道の 閉塞による無呼吸が生じる. 重症例では一晚に400 回以上に及ぶ無呼吸が反復して起きるが，無呼吸 中は窒息状態下に呼吸運動が行なわれるために, 胸腔内圧の著明な上下動（特に吸気時の強い陰 区)，空気飢餓状態，低酸素血症括よび高炭酸がス 血症に陷り，覚醒反応に上る深睡眠の久除や循環 器系への影響などが現われ，より多彩で複雑な病 像を形成する，混合型の場合は，無呼吸が先ず中 权型で始まり，途中から閉塞型に移行するもので ある。

\section{2. 教室における polysomnography の臨床成績}

教室に颃いては昭和 55 年 8 月に第 1 例の夜間 
表 1，夜間polysomnography㬰施症例

\begin{tabular}{cc|c|c|c}
\hline & & 男 & 女 & 計 \\
\hline 症 例 数 & $\mathrm{no}$ & 26 & 10 & 36 \\
年 令 & $\mathrm{yr}$ & $35 \sim 84(58.8)$ & $31 \sim 70(50.9)$ & $31 \sim 84(56.6)$ \\
身 長 & $\mathrm{cm}$ & $145 \sim 171(161.0)$ & $145 \sim 158(150.9)$ & $145 \sim 171(158.2)$ \\
体 重 & $\mathrm{kg}$ & $35.2 \sim 76(55.4)$ & $40.5 \sim 99(56.9)$ & $35.2 \sim 99(55.7)$ \\
肥满 席 & $\%$ & $-42.8 \sim 49.6(-2.1)$ & $-2 \sim 99.2(16.6)$ & $-42.8 \sim 99.2(3.1)$ \\
(Broca指数) & $\%$ & &
\end{tabular}

表 2.Polysomnographyの奏施理由

\begin{tabular}{|c|c|}
\hline 理由（症状，徵候，病名） & 例数 \\
\hline 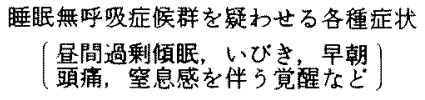 & 19 \\
\hline 甲状腺機能低下症 & 5 \\
\hline 胸郭成形術, 陳旧性肺結核 & 2 \\
\hline 慢性肺気腫 & 3 \\
\hline 重症急性呼吸不全（原因不明） & 1 \\
\hline 心不全（原因不明） & 2 \\
\hline 肺胞低換気（原因不明） & 1 \\
\hline 肥満, 肺胞低換帯 & 1 \\
\hline 術後両㑡横隔神経麻瘏 & 1 \\
\hline 㚘心症 & 1 \\
\hline 計 & 36 \\
\hline
\end{tabular}

polysomnographyを実施し，以来昭和59年11月ま でに正常人 5 名と疾患群36例について検查した。 患者群36例の性別は男26例, 女10例であり, 年令, 身長, 体重, 肥满度の範囲と平均値は表 1 のごと くであつた。

これらの症例について, polysomnographyを実 施することにした理由をまとめてみると表 2 のご とくなつた。最も多かつたのは睡眠無呼吸を疑わ せる症状に基づくものであり，昼間過㮃傾眠，い びき, 早朝頭痛, 窒息感を伴う夜間覚醒などの19 例であつた。 かかる臨床症状を呈する症例に日常 殓療の場で出会うことは決してまれではなく、ま ず疑つてみることが診断のきつ掛けを得る重要な ポイントである。生，昼間過剰傾眠，いびきな どは，患者から聞き出すことによつて始めてその 存在がわかることが多い，その他，性的不能，知 能障害, 性格の変化, 幻覚, 運動能低下, 息切れ, 不眠，心室性または洞性不整脈，徐脈，高血王，
表 3.Polysomnographyの成績のま之め一睡眠呼吸 障害の型別症例数および日中動脈血ガス分析による 呼吸不全該当例数一

\begin{tabular}{|c|c|c|}
\hline 睡眠呼吸障害の型 & 症例数 & $\begin{array}{l}\text { 日中動眽血 } \\
\text { 方哷罗不 } \\
\text { 全該当例数 }\end{array}$ \\
\hline 閉塞型睡眠無呼吸 & 12 & 1 \\
\hline 中枢型睡眠無呼吸 & 2 & 1 \\
\hline 掍合型睡眠無呼吸 & 1 & \\
\hline $\mathrm{O}_{2}$ 䬲和度低下を伴亏周期性呼吸 & 8 & 3 \\
\hline $\mathrm{O}_{2}$ 餙和度低下を伴わない周期性呼吸 & 1 & 1 \\
\hline 呼吸障害無し & 12 & \\
\hline 計 & 36 & 6 \\
\hline
\end{tabular}

肺高血厈，赤血球增加症，呼吸不全などが診断入 の手掛りとなることもある，症例の中には，ナル コレプシー，精神分裂病，心不全などの診断を受 けている例も認められる。その他の症例では, 睡 眠中の呼吸障害の存在が予想される疾病，あるい は徵候を有している例について polysomnographyが実施されていた。

36例のpolysomnographyの成績について，睡眠 呼吸障害のタイプでまとめてみると表 3 の通りで あつた。睡眠無呼吸については, 閉塞型が12例と 最子多く, 混合型 1 例, 中枢型 2 例の計15例であ つた。るた, ear oximeterによるSo $\left(\mathrm{O}_{2}\right.$ 飽和度) 低下を伴亏周期性呼吸が 8 例，伴わない周期性呼 吸が 1 例であり，全体として，36例中24例(67\%) に何らかの睡眠呼吸障害が認められた。

一方，日中の動脈血ガス分析により，呼吸不全 $\left(\mathrm{PaO}_{2} 60_{\text {TORR }}\right.$ 以下, $\mathrm{PaCO}_{2} 50_{\text {TORR }}$ 以上 $)$ が認めら れた症例は，睡眠呼吸障害を認めた 24 例中の 6 例 のみであつた（図 1)，これに対して，睡眠中の $\mathrm{So}_{2}$ 


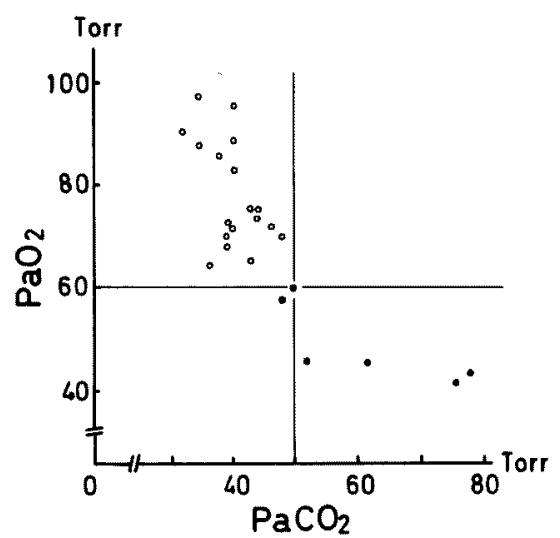

図 1. 睡眠呼吸障害を認めた症例の日中動脈血ガス所 見

$$
\left(\begin{array}{ll}
\text { ・: 呼吸不全に該当する例 } \\
0 ：
\end{array}\right)
$$

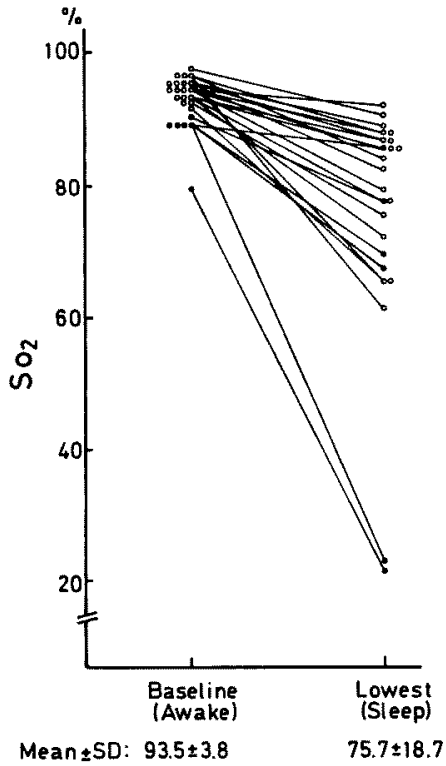

図 2、入眠前基準 $\mathrm{So}_{2}$ 值 (Baseline) と夜間最低 $\mathrm{So}_{2}$ 值 (Lowest)

-：日中動脈血ガス分析による呼吸不全例 日中動脈血ガス分析による非呼吸不全例

には明らかな低下を認めた例が多く（図 2)，夜間 polysomnophraphyによる検索の重要性を表わし ていると考えられた，すなわら，従来の昼間の検 査のみでは，呼吸不全を完全には把握し得ず，肺 の病態生理学的異常をとらえることが出来ないこ
とを示しているといえる。

\section{3. 症例}

代表的な 4 症例を提示した。

症例1，原発性肺胞低換気症候群。36才，男性。

症例2、肥満を伴わない重症の閉塞型睡眠無呼 吸症候群，小顎症。46才，男性。

症例3. Pickwick症候群。36才, 男性.

症例4. 慢性気管支炎・肺気腫. 70才，男性.

症例 1 では中权型睡眠無呼吸, 症例 2 では閉塞 型睡眠無呼吸，症例 3 では周期性低換気（一部閉 塞型無呼吸), 症例 4 では不規則呼吸と $\mathrm{So}_{2}$ 低下が 認められた。

\section{4. 睡眠無呼吸の治療}

中权型睡眠無呼吸の治療には，プロゲステロン などの薬物療法も試みられているが確実な効果は なく，むつぱら睡眠中の人工呼吸による肺胞換気 量の維持が中心である。夜間の人工呼吸には， Glennによつて開発された横隔膜pacer)を用い て，一側の横隔神経を電気刺激することによつて 換気を得る方法と, 機械的な人工呼吸器を使つて 換気を維持する万法がある。

閉塞型睡眠無呼吸の治療は，表 4 に示した方法 が施される，気管開空術は，切開後の管理や心理 的問題などを除けば，その効果は最す確実であり， 重症例に対して劇的な効果がある．中等症，軽症 例には薬物療法与試みられているが，やはり病因

表 4、閉塞型睡眠無呼吸の治療

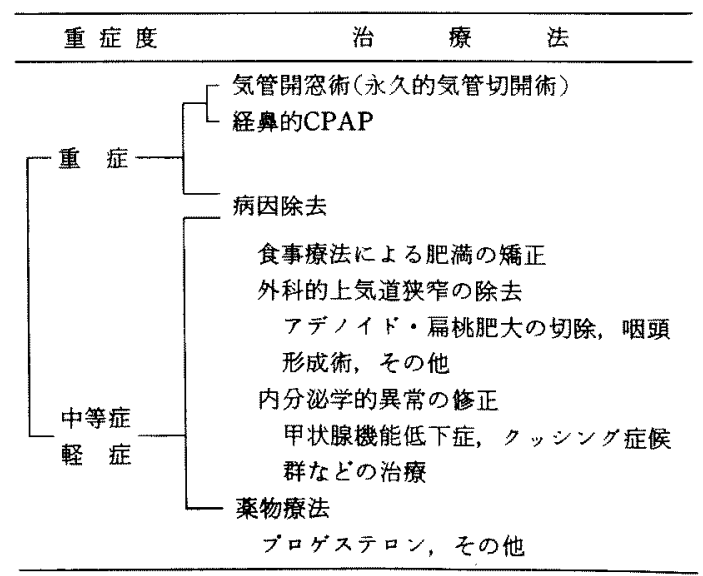




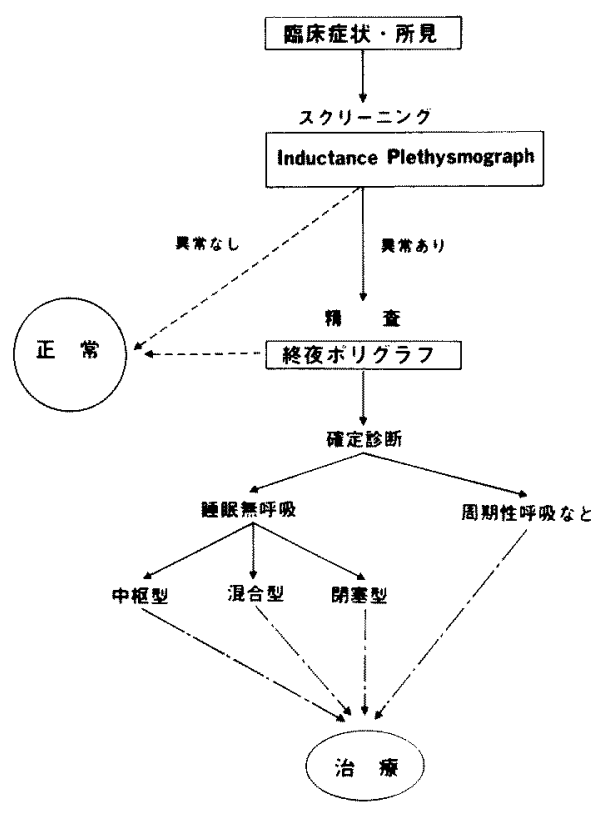

图 3.睡眠呼吸障害の䇏断手順

を除去できるるのはまず除くべきである.

中权型，閉塞型を問わず，アルコール摂取，精 神安定剤，眠剤などの服用は病態の悪化を招き， また突然死をもたらす危険があるので禁忌であ 万.

\section{5. まとめ}

睡眠中の呼吸障害の研究は, 最近10年間余りの 間に急速に進歩し，呼吸および循環障害を伴らあ らゆる病態との関連が明らかにされ，それまで十 分理解できなかつた病態の発生機序のいくつかを 明らかにしてきた。特に，慢性閉塞性肺疾患の長 期 $\mathrm{O}_{2}$ 吸入療法との関連などにおいて，今後ますま
す重要な検討課題の一つとなるものと思われる. しかし，わが国に拈ける研究は，まだその緒に ついたばかりであり，特に呼吸器科臨床医に上る 研究報告は少ない，その主な理由は，睡眠呼吸障 害の検索にはかなり高価な検查機器の設備を必要 とすること，また夜間睡眠中のpolygraphyを実施 する必要があるため，検査に携る人員確保の困難 さ，負担の大きさなどの問題が生じるためである。 現在われわれは，睡眠呼吸障害の診断手順として 図 3 のごとき流れを作つて和り，殊に検者，被験 者共に負担の軽いスクリーニング法を提案し，ま た今啳その開発，確立を推進すべきであると考兄 ている.

睡眠無呼吸症候群について教室における臨床成 績を中心に述べたが，本講演がわが国における睡 眠呼吸障害に関する研究の発展のためにいささか でも寄与することを望むものである。

\section{文献}

1) Burwell CS, et al : Extreme obesity associated with alveolar hypoventilation: A Pickwickian syndrome. Amer J Med 21: 811, 1956.

2) Gastaut $\mathrm{H}$, et al: Etude polygraphique des manifestations episodiques (hypniques et respiratoires), diurnes et nocturnes, du syndrome de Pickwick. Rev Neurol (Paris) 112 : 586, 1965.

3) Guilleminault $\mathrm{C}$, et al: Clinical overview of the sleep apnea syndromes. Guilleminault $C_{\text {, }}$ Dement WC, eds. Sleep Apnea Syndromes. Alan R Liss Inc, New York, 1978, pl.

4) Glenn WWL: Diaphragm pacing: Present status. Pace 1: 357, 1978. 